\title{
Southern California margin benthic foraminiferal assemblages record recent centennial-scale changes in oxygen minimum zone
}

\author{
Hannah M. Palmer ${ }^{1,2}$, Tessa M. Hill ${ }^{1,2}$, Peter D. Roopnarine ${ }^{3}$, Sarah E. Myhre ${ }^{4}$, Katherine R. Reyes ${ }^{1,5}$, and \\ Jonas T. Donnenfield ${ }^{1,6}$ \\ ${ }^{1}$ Bodega Marine Laboratory, University of California, Davis, Bodega Bay, California, USA \\ ${ }^{2}$ Department of Earth and Planetary Sciences, University of California, Davis, Davis, California, USA \\ ${ }^{3}$ Department of Invertebrate Zoology and Geology, California Academy of Sciences, San Francisco, California, USA \\ ${ }^{4}$ School of Oceanography, University of Washington, Seattle, Washington, USA \\ ${ }^{5}$ Department of Natural Sciences and Mathematics, Dominican University of California, San Rafael, California, USA \\ ${ }^{6}$ Geology Department, Carleton College, Northfield, Minnesota, USA
}

Correspondence: Hannah M. Palmer (hmpalmer@ucdavis.edu)

Received: 20 November 2019 - Discussion started: 9 December 2019

Revised: 20 April 2020 - Accepted: 22 April 2020 - Published: 3 June 2020

\begin{abstract}
Microfossil assemblages provide valuable records to investigate variability in continental margin biogeochemical cycles, including dynamics of the oxygen minimum zone (OMZ). Analyses of modern assemblages across environmental gradients are necessary to understand relationships between assemblage characteristics and environmental factors. Five cores were analyzed from the San Diego margin $\left(32^{\circ} 42^{\prime} 00^{\prime \prime} \mathrm{N}, 117^{\circ} 30^{\prime} 00^{\prime \prime} \mathrm{W}\right.$; 300-1175 m water depth) for core top benthic foraminiferal assemblages to understand relationships between community assemblages and spatial hydrographic gradients as well as for down-core benthic foraminiferal assemblages to identify changes in the OMZ through time. Comparisons of benthic foraminiferal assemblages from two size fractions $(63-150$ and $>150 \mu \mathrm{m})$ exhibit similar trends across the spatial and environmental gradient or in some cases exhibit more pronounced spatial trends in the $>150 \mu \mathrm{m}$ fraction. A range of species diversity exists within the modern OMZ (1.910-2.586 H, Shannon index), suggesting that diversity is not driven by oxygenation alone. We identify two hypoxic-associated species (B. spissa and $U$. peregrina), one oxic-associated species $(G$. subglobosa) and one OMZ edge-associated species (B. argentea). Down-core analysis of indicator species reveals variability in the upper margin of the OMZ (528 m water depth) while the core of the OMZ (800 $\mathrm{m})$ and below the OMZ $(1175 \mathrm{~m})$ remained stable in the last $1.5 \mathrm{kyr}$. We document expansion of the upper margin of the OMZ beginning $400 \mathrm{BP}$ on the San Diego margin
\end{abstract}

that is synchronous with other regional records of oxygenation.

\section{Introduction}

Ocean oxygenation is declining globally; rising ocean temperatures decrease oxygen solubility at the sea surface and increased stratification inhibits ventilation, leading to decreased oxygen at depth (Breitburg et al., 2018; Levin et al., 2009; Stramma et al., 2010). Expansions of oxygen minimum zones (OMZs) have already been documented, and further expansions are predicted (Bograd et al., 2008; Schmidtko et al., 2017; Stramma et al., 2010). Within the California Current system, a decline in dissolved oxygen (DO) concentration, shoaling of the hypoxic boundary, and decreased $\mathrm{pH}$ have been documented (Bakun, 2017; Bograd et al., 2008). The intensity and geographic extent of the CA margin OMZ has oscillated in response to past changes in climate and ocean temperatures on millennial timescales - weakening during cool periods and strengthening during warm periods (Cannariato and Kennett, 1999; Jaccard et al., 2014; Moffitt et al., 2014, 2015a; Ohkushi et al., 2013). Determination of timing and drivers of past expansions and contractions of OMZs is critical to developing accurate predictions of future change (Jaccard et al., 2014). 
Continental margin biogeochemical dynamics structure shelf ecosystems across space and time (Levin et al., 2009; Levin and Dayton, 2009). In particular, oxygenation is a key determinant of benthic zonation; seafloor ecosystems are subject to major turnover in response to relatively minor inferred changes in oxygenation (Levin, 2003; Levin and Dayton, 2009; Moffitt et al., 2015b). Areas of low oxygen availability typically contain low abundance and diversity of organisms (Levin, 2003; Levin and Dayton, 2009). However, several species of benthic foraminifera are adapted to survive in low-oxygen conditions and are thus present, and often abundant, in such environments (Bernhard and Gupta, 1999; Gooday et al., 2000; Kaiho, 1994, 1999; Keating-Bitonti and Payne, 2016).

\subsection{Benthic foraminifera record changes in coastal margin biogeochemistry}

Microfossil records from the Southern California Borderlands are a critical tool for understanding changes in productivity (Cannariato and Kennett, 1999; Emmer and Thunell, 2000; Stott et al., 2000), orbital and millennial-scale climate changes (Hendy, 2010; Hendy and Kennett, 2000; Taylor et al., 2015), and climate change through the Holocene (Balmaki et al., 2019; Fisler and Hendy, 2008; Friddell et al., 2003; Roark et al., 2003). Benthic foraminiferal assemblages are widely used as a proxy for changes in oxygenation through time (Balestra et al., 2018; Bernhard et al., 1997; Bernhard and Gupta, 1999; Cannariato and Kennett, 1999; Gooday, 2003; Jorissen et al., 2007; Moffitt et al., 2014; Ohkushi et al., 2013; Shibahara et al., 2007; Tetard et al., 2017). Previous work (through analysis of benthic foraminifera along environmental depth gradients and in laboratory culturing studies) documented relationships between benthic foraminiferal taxa and water depth, oxygen concentration, sediment substrate, position in the sediment matrix, nitrate availability, and organic matter availability (Bernhard et al., 1997; Bernhard and Bowser, 1999; Bernhard and Gupta, 1999; Cardich et al., 2019; Caulle et al., 2014; Douglas, 1981; Douglas and Heitman, 1979; Erdem et al., 2019; Jorissen et al., 2007; Kaiho, 1994, 1999; Mallon et al., 2012; Mazumder and Nigam, 2014; Mullins et al., 1985).

Generally, low-oxygen environments contain high abundance and low diversity of benthic foraminifera; in these settings, infaunal, elongate, thin-walled species with high porosity dominate over porcelaneous and epifaunal taxa (Bernhard et al., 1997; Douglas, 1981; Jorissen et al., 1995, 2007; Kaiho, 1994, 1999; Mazumder and Nigam, 2014). Further work has explored the relationship between foraminiferal size and oxygenation; generally volume-tosurface-area ratios of foraminiferal tests are positively correlated with dissolved oxygen, yet studies of individual taxa on the Southern California margin do not consistently show this relationship (Bitonti and Payne, 2016, 2017; Rathburn et al., 2018). Often, individual taxa of foraminifera are classified into groups based on oxygen affinity or individually identified as oxygen indicator taxa (Jorissen et al., 1995; Kaiho, 1999; Moffitt et al., 2014). In particular, bolivinid taxa are noted as low-oxygen indicator taxa (Cardich et al., 2015; Caulle et al., 2014; Mallon et al., 2012; Mullins et al., 1985). However, these relationships between foraminiferal assemblages and environmental metrics are regionally defined and cannot be applied globally; regional calibrations of the benthic foraminifera oxygen proxy are required for accurate paleoceanographic analyses (Bernhard et al., 1997; Caulle et al., 2014; Kaiho, 1999; Mallon et al., 2012; Mazumder and Nigam, 2014). Similarly, the classification of oxygenation levels varies among paleoceanographic studies (Balestra et al., 2018; Kaiho, 1994; Moffitt et al., 2015a). This study uses the following classification: oxic $\left(\left[\mathrm{O}_{2}\right]>1.5 \mathrm{~mL} \mathrm{~L}^{-1}\right)$, intermediate hypoxia or suboxic $\left(\left[\mathrm{O}_{2}\right] 1.5-0.5 \mathrm{~mL} \mathrm{~L}^{-1}\right)$, and severe hypoxia or dysoxic $\left(\left[\mathrm{O}_{2}\right]<0.5 \mathrm{~mL} \mathrm{~L}^{-1}\right.$ ) (Moffitt et al., 2015a). Although oxygenation is a dominant driver of ecosystem zonation in marginal environments, sediment substrate, organic matter availability, and nitrate availability also play important roles in structuring benthic foraminiferal assemblages. Further analysis of the interacting environmental factors along depth and environmental gradients is needed (Jorissen et al., 1995, 2007; Mullins et al., 1985; Venturelli et al., 2018).

Previous studies of oxygenation change over time from the Southern California margin focus largely on the Santa Barbara and Santa Monica basins, due to their high sedimentation rates and regular laminations (Balestra et al., 2018; Cannariato and Kennett, 1999; Christensen et al., 1994; Kaiho, 1999; Moffitt et al., 2014; Schimmelmann et al., 2013). Significantly fewer studies in the northeast Pacific investigate sediments outside of those basin environments (McGann, 2002). Further analysis is therefore needed to constrain relationships between benthic foraminifera and environmental conditions in the open continental margin where biological and chemical gradients are more variable and to identify decadal to centennial changes in OMZ dynamics.

\subsection{Regional setting}

The California margin is a well-studied system characterized by southward flow of the California Current, a strong seasonal upwelling regime bringing cold, nutrient-rich waters to the surface; high coastal productivity; and a large OMZ occurring at intermediate water depths (Checkley and Barth, 2009). The San Diego margin is dominated by two surface currents: the southward-flowing California Current and the seasonal, northward-flowing surface Davidson Current (Checkley and Barth, 2009).

An important feature of California margin coastal oceanography is the presence of a large, intermediate-depth OMZ and carbon maximum zone (CMZ), from approximately 500 to $1000 \mathrm{~m}$ water depth (Helly and Levin, 2004; Stramma et al., 2010). The intensity and spatial extent of 
the modern California margin OMZ is driven by physical mixing of well-oxygenated surface water, biological activity at the surface and at depth, and intrusion of lower-oxygen bottom waters (Gilly et al., 2013). Both physical processes (temperature-dependent diffusion from atmosphere, mixing, stratification, deep water circulation) and biological processes (primary productivity at the surface and respiration at depth) control the intensity and extent of OMZs (Gilly et al., 2013; Helly and Levin, 2004).

Here we utilize the spatial variability of the continental margin as a natural laboratory to analyze relationships between core top, modern benthic foraminiferal assemblages, and in situ measurements of environmental parameters (temperature, oxygenation, carbonate chemistry). We then quantify benthic foraminiferal assemblages down core to understand past environmental change.

\section{Methods}

\subsection{Study site}

The San Diego margin is located in the Southern California Borderlands in the eastern North Pacific (Fig. 1). The margin slopes downward to a depth of approximately $1200 \mathrm{~m}$ at a distance of $30 \mathrm{~km}$ normal to shore (Fig. 1) and is bounded by a bathymetric rise ( $600 \mathrm{~m}$ water depth) to the west. All hydrographic data and sediment cores used in this study were collected by the San Diego Coastal Expedition aboard the $\mathrm{R} / \mathrm{V}$ Melville in December 2012 by a team from the Scripps Institution of Oceanography.

\subsection{Oceanographic data collection}

Bottom water temperature, salinity, and dissolved oxygen concentration were collected at each coring location using a Sea-Bird CTD (SBE9), with a dissolved oxygen probe (SeaBird Electronics sensor SBE43). Carbonate chemistry was completed using in situ bottle sampling for $\mathrm{pH}$ and total dissolved inorganic carbon (DIC) and was previously published (Nam et al., 2015; Takeshita et al., 2015). Bottom depths were measured acoustically at each site.

\subsection{Sediment cores}

Five sediment cores collected along a depth transect from 300 to $1175 \mathrm{~m}$ depth were selected for use in this study (Fig. 1; Table 1). Short $(15-31 \mathrm{~cm})$ surface sediment cores were collected along the coastal margin using a deep-sea multicore with $9 \mathrm{~cm}$ diameter cores. Each core was divided into $1 \mathrm{~cm}$ intervals aboard the ship and immediately frozen. Sediments were not stained upon retrieval; thus, we could not carry out an analysis of live vs. dead or depth habitat of these species. Total organic matter of core top sediments was measured as percent ash-free dry weight and previously published in Grupe et al. (2015) (Grupe et al., 2015). Sub- samples were each disaggregated in deionized water, washed over a $63 \mu \mathrm{m}$ sieve, and oven-dried at $50{ }^{\circ} \mathrm{C}$.

\subsection{Foraminiferal assemblages}

Assemblages were counted from the $>150$ and $63-150 \mu \mathrm{m}$ fraction for comparison between the size fractions. Sediments were split using a sediment splitter and dry sieved; a minimum of 300 foraminifera per sediment sample (in the $>150 \mu \mathrm{m}$ fraction) were identified and counted for all core top samples to provide a representative assemblage, unless fewer than 300 specimens were present in the entire sample. Identification of benthic foraminiferal taxa was based on previously published descriptions and images of benthic foraminifera (see the Supplement, Fig. S4, for images of dominant taxa and taxonomic reference list) (Balestra et al., 2018; Erdem and Schönfeld, 2017; Keating-Bitonti and Payne, 2017; Moffitt et al., 2014; Setoyama and Kaminski, 2015). Assemblages in the $63-150 \mu \mathrm{m}$ fraction were quantified from the same sediment fraction as the $>150 \mu \mathrm{m}$ to allow for comparison of abundance between the two groups. Down-core assemblages were quantified in the $>150 \mu \mathrm{m}$ size fraction (see discussion below), and a minimum of 150 foraminifera per sediment sample were counted in all downcore samples unless fewer than 150 specimens were present in the sample (Mallon et al., 2012). Assemblage counts are standardized to the volume $\left(63.62 \mathrm{~cm}^{3}\right)$ of the sampled cylinder of the sediment (core). Core top sediment $(0-1,1-$ $2 \mathrm{~cm}$ ) calcareous benthic foraminiferal assemblages were described for all cores. Complete down-core records of benthic foraminiferal assemblages were examined at 1 or $2 \mathrm{~cm}$ intervals for cores MV1217-2-3 (0-18 cm, sampled at $1 \mathrm{~cm}$ interval, $528 \mathrm{~m}$ water depth) and MV1217-1-3 (0-10 cm, sampled at $1 \mathrm{~cm}$ interval; $10-20 \mathrm{~cm}$, sampled at $2 \mathrm{~cm}$ interval, $800 \mathrm{~m}$ water depth). In order to build a longer temporal record at $1175 \mathrm{~m}$ we combine two multicores: core MV1217-4-3 (0$10 \mathrm{~cm}$, sampled at $1 \mathrm{~cm}$ interval) and MV1217-4-1 (sampled at $10-16 \mathrm{~cm}, 2 \mathrm{~cm}$ interval, $1175 \mathrm{~m}$ water depth).

The Shannon index of diversity was used to describe foraminiferal diversity (Peet, 1974). Analysis of variance (ANOVA) was used to analyze and determine the differences between assemblages in two size fractions: $>150$ and 63-150 $\mu \mathrm{m}$. Distance-based redundancy analysis (dbRDA) with Bray-Curtis distances was used to ordinate core top assemblages and examine relationship to environmental variables. Nonmetric multidimensional scaling ordination, using square root transformation of assemblage species counts and Bray-Curtis similarities, was completed to identify relatedness between assemblages through time. All multivariate analyses were completed using the vegan $\mathrm{R}$ package (Myhre et al., 2017; Oksanen et al., 2013). 


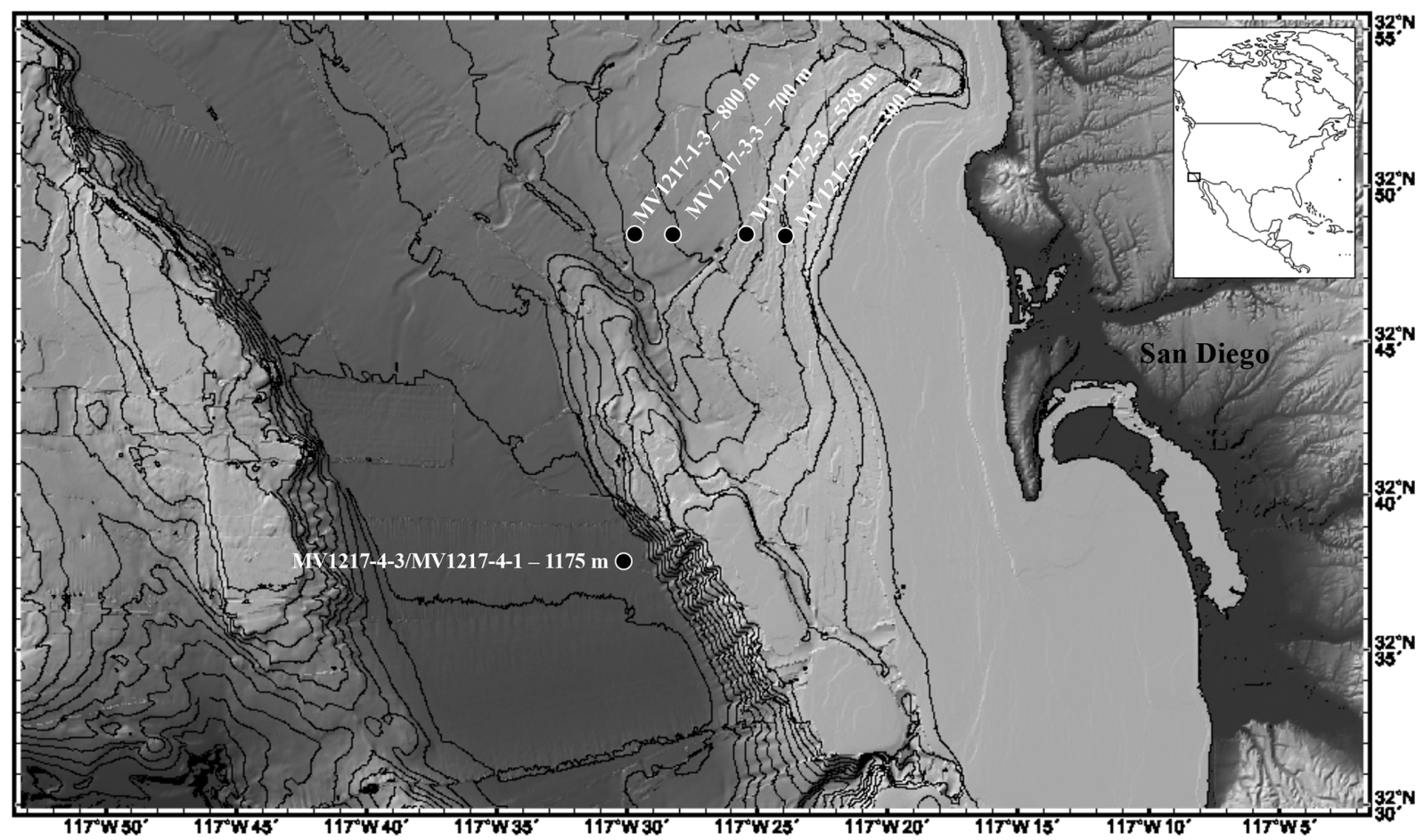

Figure 1. Map of cores used in this study. The cores were collected along a transect perpendicular to shore at the following water depths: 300 , $528,700,800$, and $1175 \mathrm{~m}$. Core top samples were analyzed for all cores. Cores MV1217-2-3, MV1217-1-3, and MV1217-4-3/MV1217-4-1 were analyzed down core.

Table 1. Data for cores used in this study. Temperature, dissolved oxygen, $\mathrm{pH}$, and salinity were measured in bottom water directly above each coring site.

\begin{tabular}{|c|c|c|c|c|c|c|c|c|c|}
\hline Core name & $\begin{array}{r}\text { Water } \\
\text { depth } \\
(\mathrm{m})\end{array}$ & Latitude & Longitude & $\begin{array}{r}\text { Core } \\
\text { length } \\
(\mathrm{cm})\end{array}$ & $\begin{array}{r}\text { Temperature } \\
\left({ }^{\circ} \mathrm{C}\right)\end{array}$ & $\begin{array}{r}\text { Dissolved } \\
\text { oxygen } \\
\left(\mathrm{mLL}^{-1}\right)\end{array}$ & $\mathrm{pH}$ & $\begin{array}{r}\text { Salinity } \\
(\mathrm{psu})\end{array}$ & $\begin{array}{r}\text { Total } \\
\text { organic } \\
\text { matter } \\
(\% \mathrm{wt})\end{array}$ \\
\hline MV1217-5-2 & 300 & 32.8100166 & 117.468100 & 16 & 8.614 & 1.54 & 7.65 & 34.145 & 6.8 \\
\hline MV1217-2-3 & 528 & 32.8100333 & 117.416583 & 26 & 6.622 & 0.35 & 7.57 & 34.313 & 11.7 \\
\hline MV1217-3-3 & 700 & 32.8099666 & 117.450966 & 20 & 5.898 & 0.26 & 7.56 & 34.348 & 13.9 \\
\hline MV1217-1-3 & 800 & 32.8095166 & 117.506933 & 20 & 5.049 & 0.29 & 7.56 & 34.405 & 14.2 \\
\hline MV1217-4-3/1 & 1175 & 32.6333333 & 117.499883 & 16 & 3.823 & 0.58 & 7.59 & 34.501 & 14.7 \\
\hline
\end{tabular}

\subsection{Radiocarbon-based chronology}

Cores from two sites (528 $\mathrm{m}$ water depth, MV1217-2-3; $1175 \mathrm{~m}$ water depth, MV1217-4-1 and MV1217-4-3) were selected for radiocarbon $\left({ }^{14} \mathrm{C}\right)$ dating using mixed planktonic foraminifera. Core MV1217-2-3 (528 m) was sampled at three $1 \mathrm{~cm}$ intervals $(11-12,16-17,25-26 \mathrm{~cm})$. To generate an age model for the multicores at $1175 \mathrm{~m}$ water depth, core MV1217-4-3 (1175 m) was sampled at one $1 \mathrm{~cm}$ interval $(5-6 \mathrm{~cm})$, and core MV1217-4-1 $(1175 \mathrm{~m})$ was sampled at two $1 \mathrm{~cm}$ intervals $(10-11,20-21 \mathrm{~cm})$ (Table 2). Radiocarbon analysis was completed at the Lawrence Livermore National Laboratory using $\delta^{13} \mathrm{C}$ assumed values following the convention of Stuiver and Polach (1977). The quoted age was given in radiocarbon years using the Libby half-life of 5568 years. The Calib7.1 calibration program was used to calibrate ages using a reservoir age of 220.0 440.0 (Ingram and Southon, 1996; Stuiver and Polach, 1977).

\section{Results}

\subsection{Vertical profiles, sediment characterization of San Diego margin}

Across the depth profile, bottom water temperature decreased steadily with depth (300 to $1175 \mathrm{~m}$ ) ranging from 
Table 2. Radiocarbon ages of mixed planktonic foraminifera from MV1217-2-3 (528 m water depth), MV1217-4-3 (1175 m water depth), and MV1217-4-1 (1175 m water depth).

\begin{tabular}{llrrrrrrr}
\hline Core & $\begin{array}{l}\text { Sample } \\
\text { interval }\end{array}$ & $\begin{array}{r}\text { Age } \\
\left(\begin{array}{l}14 \\
\text { C years })\end{array}\right.\end{array}$ & $\begin{array}{r}\text { maximum } \\
\text { calendar } \\
\text { age range }\end{array}$ & $\begin{array}{r}1 \sigma \\
\text { minimum } \\
\text { calendar } \\
\text { age range }\end{array}$ & $\begin{array}{r}\text { Age in } \\
\text { calendar } \\
\text { years }\end{array}$ & $\begin{array}{r}\text { Sedimentation } \\
\text { rate } \\
\left(\mathrm{cm} \mathrm{kyr}^{-1}\right)\end{array}$ & \pm \\
\hline MV1217-2-3 & $11-12 \mathrm{~cm}$ & 1230 & 30 & 1403 & 1319 & 1361 & 16.9 & 1.0 \\
MV1217-2-3 & $16-17 \mathrm{~cm}$ & 2085 & 30 & 602 & 474 & 538 & 6.1 & 0.2 \\
MV1217-2-3 & $25-26 \mathrm{~cm}$ & 2405 & 35 & 237 & 107 & 172 & 24.6 & 0.1 \\
MV1217-4-3 & $5-6 \mathrm{~cm}$ & 670 & 35 & 1950 & 1837 & 1893.5 & 42.2 & 11.3 \\
MV1217-4-1 & $10-11 \mathrm{~cm}$ & 960 & 30 & 1630 & 1518 & 1574 & 15.6 & 0.2 \\
MV1217-4-1 & $20-21 \mathrm{~cm}$ & 1840 & 35 & 817 & 698 & 757.5 & 12.3 & 0.4 \\
\hline
\end{tabular}

$8.6(300 \mathrm{~m})$ to $3.8^{\circ} \mathrm{C}(1175 \mathrm{~m})$ (Fig. 2 , Table 1$)$. Salinity (not plotted here) had a mean of 34.4 psu ranging from 34.1 to $34.5 \mathrm{psu}$. Water column DO measurements collected directly above each coring site show oxic conditions at $300 \mathrm{~m}\left(1.54 \mathrm{~mL} \mathrm{~L}^{-1}\right)$ above the OMZ, intermediate hypoxia at $1175 \mathrm{~m}\left(0.58 \mathrm{mLL}^{-1}\right)$ below the OMZ, and severe hypoxia at $528 \mathrm{~m}\left(0.35 \mathrm{~mL} \mathrm{~L}^{-1}\right)$ at the upper edge of the OMZ, as well as within the $\mathrm{OMZ}$ at $700\left(0.26 \mathrm{mLL}^{-1}\right)$ and $800 \mathrm{~m}$ $\left(0.29 \mathrm{~mL} \mathrm{~L}^{-1}\right)$. Although not greatly variable, a $\mathrm{pH}$ minimum occurs at $700 \mathrm{~m}(7.55)$ and is higher at 300 (7.65) and $1175 \mathrm{~m}$ (7.59) (Fig. 2, Table 1). Total organic matter increased with depth $(6.8 \%-14.7 \%$ ash free dry weight, Table 1). These results are consistent with previous analyses of the California margin OMZ and CMZ (Helly and Levin, 2004).

\subsection{Benthic foraminiferal assemblages across a modern environmental gradient}

Relative abundance of benthic foraminifera was quantified for all sites in the $0-1$ and $1-2 \mathrm{~cm}$ intervals. We compared the $0-1 \mathrm{~cm}$ interval to the $1-2 \mathrm{~cm}$ interval to assess if depth habitat of any species determined their relative abundance in the core top assemblage. Specimens were not Rose Bengal stained; thus their presence in any interval does not indicate that they were living at the time of collection. We do not identify any significant relationship between relative abundance of a species and depth interval (ANOVA; in all cases $p>0.05$ or $r^{2}$ is $\left.<0.001\right)$. Foraminiferal abundance is low ( $<100$ individuals) in some of the samples from 0 to $1 \mathrm{~cm}$. Thus, in order to utilize sufficient numbers of individuals and because there were no significant differences in abundance of species between $0-1$ and $1-2 \mathrm{~cm}$, for the rest of the discussion we refer to the $0-2 \mathrm{~cm}$ fraction as the core top material (Figs. 2 and 3). Calcareous taxa dominated the assemblage at every site; agglutinated foraminifera made up $0 \%(300 \mathrm{~m})$ to $21 \%$ $(700 \mathrm{~m})$ of the assemblage. Due to their propensity for degradation and to remain consistent with other regional studies, we exclude agglutinated taxa and all values are reported as percent of total calcareous taxa for the remainder of the text
(Balestra et al., 2018; Kaiho, 1994; Moffitt et al., 2014; Venturelli et al., 2018).

Total abundance of foraminifera decreases with depth (Fig. 2). Core top assemblages were dominated by Bolivina argentea, Epistominella sp., Uvigerina peregrina, Globocassidulina subglobosa, Cassidulina carinata, and Bolivina spissa, in order of decreasing abundance (see Fig. S4 for images of dominant taxa). These dominant taxa make up $80 \%$ of all calcareous foraminifera counted across all core top samples. All other species each represent less than four percent of the total assemblage across all core tops. The following taxa are found at all five water depths: Bolivina argentea, Bolivina spissa, Bulimina spp., Cibicidoides sp., Epistominella sp., Globobulimina pacifica, Globocassidulina subglobosa, Globobulimina ovata, Nonionella stella, Quinqueloculina sp. and Uvigerina peregrina.

First, we report the benthic foraminiferal assemblage from the $>63 \mu \mathrm{m}$ size fraction; we then report on a comparison between the $63-150$ and $>150 \mu \mathrm{m}$ size fractions. The assemblage at $300 \mathrm{~m}$ is dominated by G. subglobosa $(28 \%), B$. argentea (25\%), U. peregrina (10\%), Epistominella sp. (8\%), and Bolivina spissa (6\%); species richness is 24 and diversity $(H)$ is 2.133 . The assemblage at $528 \mathrm{~m}$ is dominated by B. argentea $(37 \%)$, U. peregrina (23\%), Epistominella $\mathrm{sp}$. $(15 \%)$, C. carinata (6\%), and G. subglobosa (5\%); species richness is 25 and diversity $(H)$ is 1.910 . The assemblage at $700 \mathrm{~m}$ is dominated by Epistominella sp. (29\%), C. carinata (15\%), U. peregrina (13\%), G. subglobosa (11\%), B. argentea (10\%), and B. spissa (7\%); species richness is 23 and diversity $(H)$ is 2.249 . The assemblage at $800 \mathrm{~m}$ is dominated by B. spissa (16\%), U. peregrina (16\%), Epistominella sp. (13\%), C. carinata (10\%), Cibicidoides sp. $(10 \%)$, and Globobulimina ovata (13\%); species richness is 25 and diversity $(H)$ is 2.586 . The assemblage at $1175 \mathrm{~m}$ is dominated by $C$. carinata ( $25 \%)$, Epistominella sp. (20\%), G. subglobosa (8\%), and B. spissa (6\%); species richness is 25 and diversity $(H)$ is 2.389 (Fig. 2). 


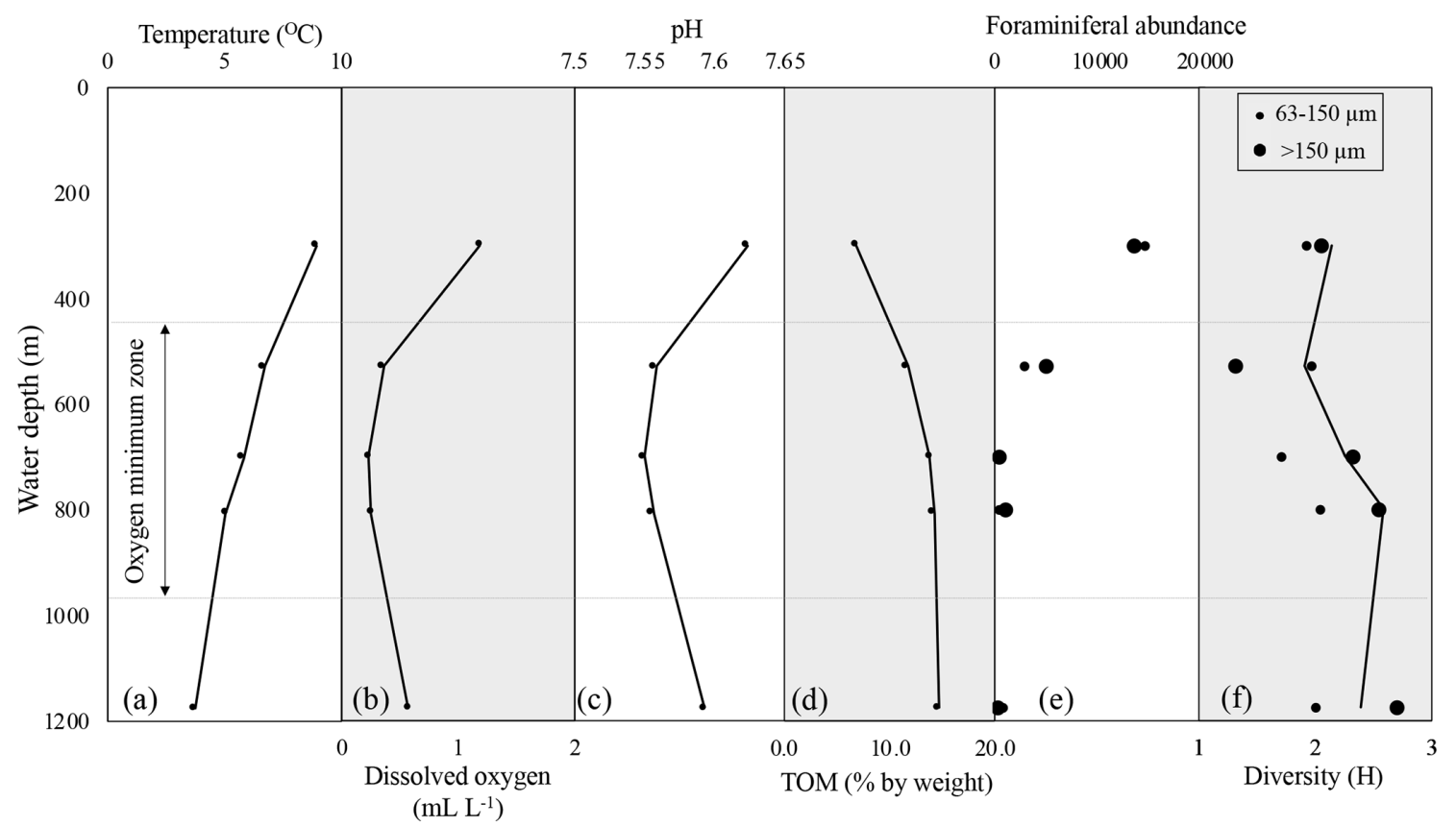

Figure 2. Profiles of temperature (a), dissolved oxygen (b), pH (c), and total organic matter (\% by weight) (d) across the depth transect. Foraminiferal abundance (total calcareous foraminifera) (e) and diversity (Shannon index, $H$ ) (f) are shown for two size fractions. In panels (e) and (f), large black dots are $>150 \mu \mathrm{m}$ size fraction, small black dots are 63-150 $\mu \mathrm{m}$ size fraction, and the black line on the diversity plot represents trends from the complete assemblage $(>63 \mu \mathrm{m})$. Assemblage counts are standardized to the volume $\left(63.62 \mathrm{~cm}^{3}\right)$ of the sampled cylinder of the sediment (core). Dashed gray line shows approximate boundaries of the oxygen minimum zone.

\subsection{Comparison of benthic foraminifera in two size fractions}

Comparison of foraminiferal abundance between the 63-150 and $>150 \mu \mathrm{m}$ size fractions shows higher abundance in the small fraction at 300,700 , and $1175 \mathrm{~m}$ and higher abundance in the large size fraction at 528 and $800 \mathrm{~m}$. Several taxa are found in both size fractions at all five water depths: Globocassidulina subglobosa and Epistominella sp. Four species have significantly different relative abundances between size classes; three are more likely to be found in the $63-150 \mu \mathrm{m}$ size fraction (C. carinata, Epistominella sp., and G. subglobosa), and one species (U. peregrina) is significantly more likely to be found in the $150 \mu \mathrm{m}$ size fraction (ANOVA, $p<0.05$ for all, Fig. 3).

In the $>150 \mu \mathrm{m}$ size fraction, species diversity $(H)$ ranges from 1.316 to 2.700 ; minimum diversity $(H)$ is found at $528 \mathrm{~m}$ (1.316) and maximum diversity $(H)$ is found at $1175 \mathrm{~m}$ (2.700). In comparison, in the $63-150 \mu \mathrm{m}$ size fraction, species diversity $(H)$ ranges from 1.710 to 2.042 ; minimum diversity $(H)$ is found at $700 \mathrm{~m}(1.710)$ and maximum diversity $(H)$ is found at $800 \mathrm{~m}(2.042)$ (Fig. 2). Species diversity is greater in the $>150 \mu \mathrm{m}$ size fraction relative to the $63-150 \mu \mathrm{m}$ size fraction at all sites except the site at $528 \mathrm{~m}$ (Fig. 2).

When we consider the complete assemblage ( $>63 \mu \mathrm{m}$ ) we can classify the most abundant species into four groups based on their trends relative to the OMZ (Fig. 3). Two species are more abundant within the OMZ: B. spissa and U. peregrina; we identify these species as dysoxic indicator species. One species is less abundant within the OMZ relative to sites outside of the range of the OMZ: G. subglobosa; we identify this species as an oxic indicator species (Kaiho, 1999). Two species increase in abundance with water depth: $C$. carinata and Epistominella sp. One species is most abundant near the uppermost edge of the OMZ: B. argentea; this species may be edge associated (Mullins et al., 1985). Importantly, when we consider only the $>150 \mu \mathrm{m}$ size fraction, we observe the same trends: high abundance in OMZ (B. spissa and U. peregrina), low abundance in OMZ (G. subglobosa), increased abundance with depth (C. carinata and Epistominella sp.), and OMZ edge associated (B. argentea) (Fig. 3). Generally, we find that trends across depth are similar between the complete $(>63 \mu \mathrm{m})$ and large size fraction $(>150 \mu \mathrm{m})$ or are more pronounced in the $>150 \mu \mathrm{m}$ size fraction compared to the $63-150 \mu \mathrm{m}$ size fraction (Fig. 3). In some taxa, trends in both size fractions are similar across depth (B. spissa, Epistominella sp., G. subglobosa, C. carinata) (Fig. 3). For other taxa, we observe a low relative abundance of a species in the $(63-150 \mu \mathrm{m})$ fraction throughout all water depths, while for the same species in the $>150 \mu \mathrm{m}$ size fraction, we observe a pronounced trend through depth (U. peregrina, B. argentea) (Fig. 3). 


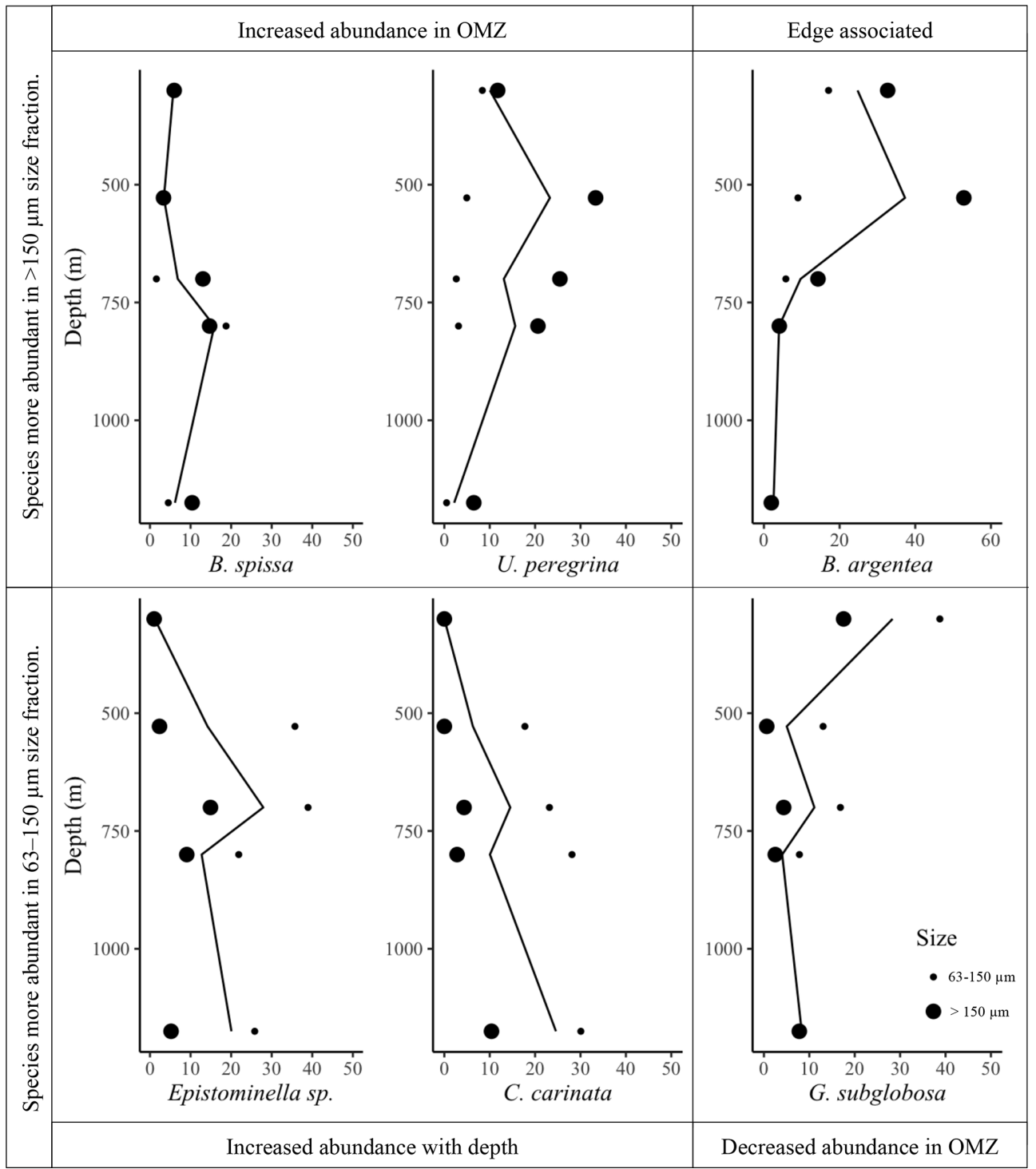

Figure 3. Relative abundance of foraminiferal species (percent of total calcareous taxa) in core top sample $(0-2 \mathrm{~cm})$ vs. water depth (m). Large black dots are $>150 \mu \mathrm{m}$ size fraction, small black dots are $63-150 \mu \mathrm{m}$ size fraction, and black lines represent trends considering the complete assemblage $(>63 \mu \mathrm{m})$.

To further analyze these trends, we completed a pairwise analysis of relative abundances of benthic foraminifera and environmental parameters. DO concentrations and $\mathrm{pH}$ are correlated at all water depths; here we chose to compare foraminiferal abundances to dissolved oxygen, yet we acknowledge that these affiliations may be driven by the combined effect of the OMZ and CMZ. When we analyze the complete assemblage ( $>63 \mu \mathrm{m})$ we identify a significant positive correlation between $G$. subglobosa and dissolved oxygen $\left(r^{2}=0.76, p<0.05\right)$ and temperature $\left(r^{2}=0.64\right.$, $p<0.05)$ and a significant negative correlation between $G$. subglobosa and total organic matter $\left(r^{2}=-0.72, p<0.05\right)$. If we analyze the $>150 \mu \mathrm{m}$ size fraction only, we identify the same significant positive correlation between DO and G. sub- globosa $\left(r^{2}=0.96, p<0.05\right)$ and also identify a positive correlation between $C$. carinata and water depth; abundance of this species increases with depth $\left(r^{2}=0.93, p<0.05\right)$. When we analyze the $63-150 \mu \mathrm{m}$ size fraction alone, we identify the same trends as observed in the $>150 \mu \mathrm{m}$ fraction: a significant positive correlation between $G$. subglobosa and dissolved oxygen $\left(r^{2}=0.90, p<0.05\right)$ and a significant positive correlation between $C$. carinata and water depth $\left(r^{2}=0.88\right.$, $p<0.05)$. In the $63-150 \mu \mathrm{m}$ fraction we also identify a significant negative correlation between $U$. peregrina and water depth $\left(r^{2}=-0.95, p<0.05\right)$. We do not identify significant correlations between any other taxa and environmental parameter. 


\subsection{Multivariate analyses of benthic foraminiferal assemblage}

Multivariate statistical analysis (using distance-based redundancy analysis) of core top assemblages identifies several taxa that contribute most strongly to the ordination of the assemblages ( $G$. subglobosa, U. peregrina, B. argentea) (Fig. S1 in the Supplement). Oxygenation operates on an axis - separating sites at 300 and $1175 \mathrm{~m}$ from the three OMZ sites 528,700 , and $800 \mathrm{~m}$. Temperature operates on a second axis (Fig. S1). Our findings support previous works that identify $G$. subglobosa with higher-oxygen environments and $B$. argentea and $U$. peregrina with lower-oxygen environments (Bernhard et al., 1997; Kaiho, 1994, 1999; Moffitt et al., 2014).

\subsection{Age model development}

Radiocarbon dating of two cores yielded variable sedimentation rates, from 6.1 to $42.2 \mathrm{~cm} \mathrm{kyr}^{-1}$ (error of \pm 11.3 , see Table 2). An age model was developed for each core based on linear interpolation between radiocarbon dates (Fig. S2). Core MV1217-3-3 (800 m water depth) was not radiocarbon dated; for this core we apply an average sedimentation rate $\left(19.6 \mathrm{~cm} \mathrm{kyr}^{-1}\right)$ generated from the core above $(528 \mathrm{~m})$ and below $(1175 \mathrm{~m})$ this core. All following results will be discussed in age (years before present).

\subsection{Temporal change in benthic foraminiferal assemblages}

Down-core assemblages were quantified in three cores (from 528,800 , and $1175 \mathrm{~m}$ water depth) in the $>150 \mu \mathrm{m}$ size fraction only, following results from core top analysis (see Sect. 4.1). Down-core assemblages contained similar species to core tops. Down-core assemblages were dominated by (in descending order) Uvigerina peregrina, Bolivina spissa, Bolivina argentea, Globobulimina sp., Cibicidoides sp., and Epistominella sp. These dominant taxa make up more than $75 \%$ of all foraminifera counted across all cores and subsamples. All other species each account for less than $5 \%$ of total assemblages across all cores and depths. The total number of species in each sample ranged from 11 to 26 , which is comparable to the number of species found in the core tops.

Multivariate statistical analysis (using nonmetric multidimensional scaling) of down-core assemblages and core top assemblages shows that, through time, assemblage similarity within sites exceeds similarity to assemblages at any other site (Fig. S3). In multivariate space, the difference between sites across space is greater than within any one site through time. For this reason, we subsequently discuss change in assemblage through time at each site independently.

At $528 \mathrm{~m}$ water depth, foraminiferal assemblages vary through time, with a notable shift occurring at $400 \mathrm{BP}$. Diversity decreases from $400 \mathrm{BP}$ to the present, which is con- current with a decrease in oxic indicator taxa G. subglobosa, an increase in dysoxic indicator $U$. peregrina, and a major increase in the proportion of $B$. argentea (Fig. 4).

At $800 \mathrm{~m}$ water depth, we do not document a significant shift in relative abundance of oxic indicators or dysoxic indicators over time, or a significant change in diversity over the interval examined (Fig. 4). We interpret these assemblages to reflect environmental stability over the past $1.5 \mathrm{kyr}$ (Fig. 4). At $1175 \mathrm{~m}$ water depth, we document little change in relative abundance of oxic and dysoxic indicator species from 200 to $800 \mathrm{BP}$. Beginning at $200 \mathrm{BP}$, we document an increase in $B$. spissa but no change in U. peregrina (Fig. 4).

\section{Discussion}

\subsection{Benthic foraminiferal assemblages across a modern environmental gradient}

Analysis of benthic foraminifera from two size fractions (63150 and $>150 \mu \mathrm{m}$ ) across a modern environmental gradient improves our understanding of benthic foraminifera as a proxy for past change. The total number of foraminifera in each size class varies with depth (Fig. 2). A range of species diversity exists within the $\mathrm{OMZ}$, suggesting that diversity is not driven by oxygenation alone (Fig. 2).

In most cases, trends of relative abundance of benthic foraminifera across space are similar between the complete assemblage $(>63 \mu \mathrm{m})$ and the $>150 \mu \mathrm{m}$ size fraction or trends in the $>150 \mu \mathrm{m}$ size fraction are more pronounced than in the complete assemblage (Fig. 3). Trends across the OMZ gradient are similar in both size fractions (63-150 and $>150 \mu \mathrm{m})$ in G. subglobosa, Epistominella sp., and C. carinata. If one were to interpret the combined assemblage or the $>150 \mu \mathrm{m}$ assemblage in these species, the results would be similar, despite these species being higher in abundance in the small size fraction. Two species (B. argentea and $U$. peregrina) are present in the $63-150 \mu \mathrm{m}$ size fraction in all sites in similar (low) relative abundance, while in the $>150 \mu \mathrm{m}$ fraction, we document distinct trends in relative abundance of these two species across space (Fig. 3). This is noteworthy as it may indicate that these species are able to tolerate a range of environmental conditions, and thus are present in small numbers and small shell sizes at all sites, but that in certain environments these species are able to thrive and outcompete other species, thus allowing them to grow to larger sizes (De Villiers, 2004; Gooday, 2003; Levin et al., 2010). This is supported by previous work showing that environmental conditions do not play a role in determining the volume of benthic foraminiferal proloculus (skeletal remains of initial cell), while volume and volume-to-surface-area ratio of adult benthic foraminifera are controlled by dissolved oxygen within low-oxygen environments (Keating-Bitonti and Payne, 2018). 


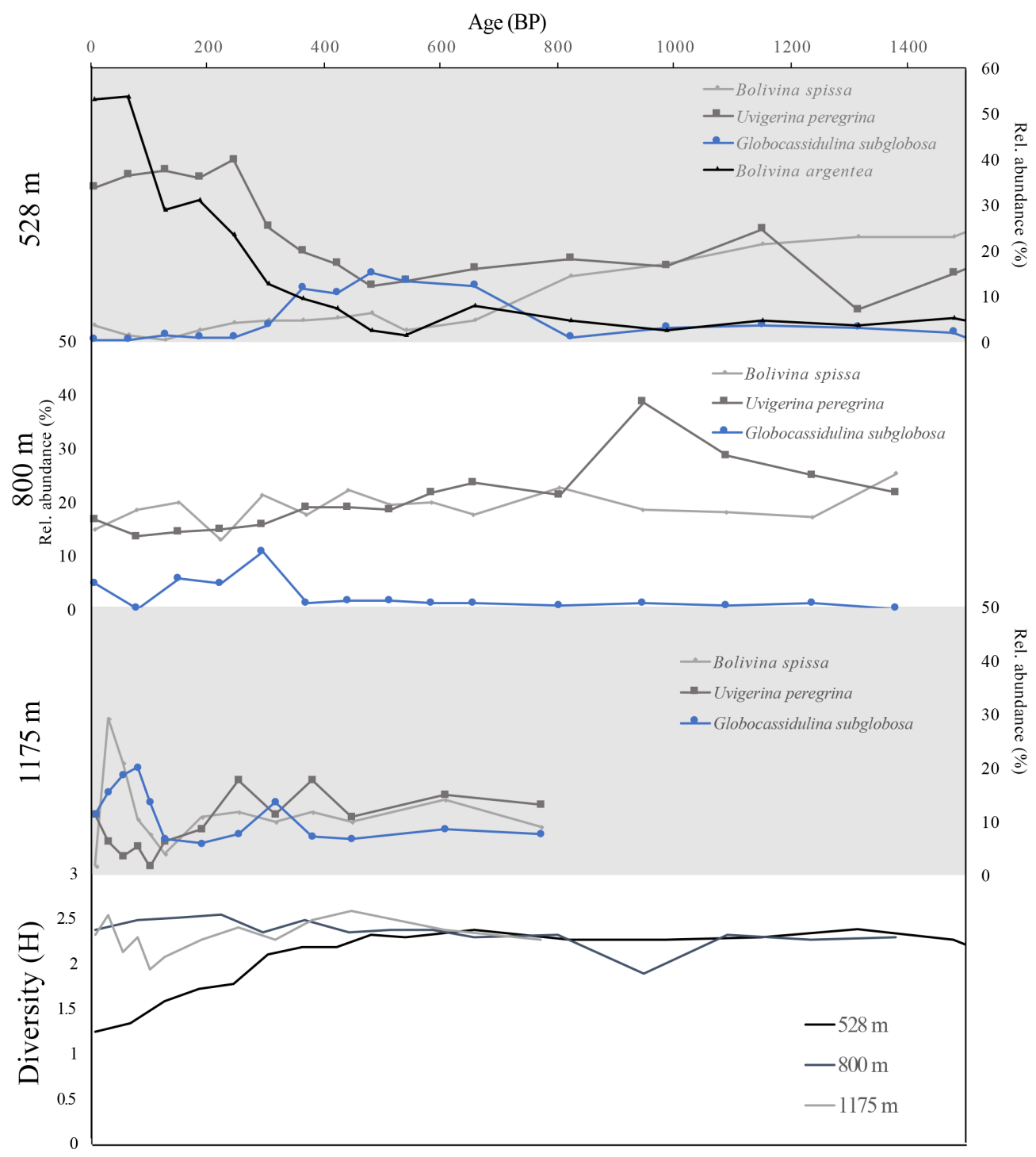

Figure 4. Top three panels show relative abundance of two species of hypoxia indicator foraminifera (B. spissa and $U$. peregrina, gray lines) and one species of oxic indicator foraminifera ( $G$. subglobosa, blue lines) from the $>150 \mu \mathrm{m}$ size fraction down-core through time, in years before present for cores from three water depths $(528,800,1175 \mathrm{~m})$. Top panel also includes relative abundance of $B$. argentea (edge associated). Bottom panel shows diversity (Shannon's index, $H$ ) through time for three cores.

In the Southern California Borderlands, the disciplinary convention has largely been to focus on the $>150 \mu \mathrm{m}$ size fraction; therefore quantifying this fraction is necessary for comparison to previously published studies (Balestra et al., 2018; Cannariato and Kennett, 1999; Moffitt et al., 2014). Our findings show that spatial trends in the $>150 \mu \mathrm{m}$ size fraction generally reflect those found in the $>63 \mu \mathrm{m}$ size fraction or are muted by the inclusion of the $63-150 \mu \mathrm{m}$ size fraction (Fig. 3). Results from a similar study in the Arabian Sea OMZ showed that assemblages were similar within the $63-125 \mu \mathrm{m}$ fraction and $>125 \mu \mathrm{m}$ fraction, and interpretation of the larger fraction was more useful to compare results to most paleoceanographic studies (Caulle et al., 2014).
Thus, we recommend that workers utilize the $>150 \mu \mathrm{m}$ size fraction for analysis when targeting indicator taxa such as B. argentea, B. spissa, U. peregrina, and G. subglobosa or when assessing trends across the OMZ gradient. However, it is useful to quantify the complete $>63 \mu \mathrm{m}$ assemblage in a subset of samples to ascertain whether there are important species or trends being missed. If the target of a project is to quantify changes in the ecology of a site or in specific metrics such as diversity, shell size, or shell weight, we recommend the inclusion of the complete assemblage $(>63 \mu \mathrm{m})$. We acknowledge that the identification of microfossils as a tool for paleoceanographic interpretation contains inherent uncertainty due to variability in identification of species be- 
tween observers and within single observers (Al-Sabouni et al., 2018; Fox et al., 2018; Hsiang et al., 2019). Further, it has been shown that there is a correlation between size of specimen and accuracy of identification, meaning that the inclusion of the smaller specimens in the $>63 \mu \mathrm{m}$ fraction may reduce the accuracy of identification (Fox et al., 2018). Given this uncertainty, in the subsequent text we focus only on spatial and environmental trends that change by a minimum of $10 \%$ relative abundance across the depth transect or through time.

In order to better compare to other similar studies from the Southern California Borderlands, for the remainder of the discussion we analyze the $>150 \mu \mathrm{m}$ fraction only. We identify two hypoxic-associated species (B. spissa and $U$. peregrina), one oxic-associated species ( $G$. subglobosa) and one OMZ edge-associated species (B. argentea). These trends are shown both in the $>150 \mu \mathrm{m}$ assemblage and in the complete assemblage ( $>63 \mu \mathrm{m}$ ) (Fig. 3). Not surprisingly, these taxa are commonly used as indicator species in previous studies (Balestra et al., 2018; Cannariato and Kennett, 1999; Moffitt et al., 2014). The species we identify as dysoxic and edge associated (B. spissa, U. peregrina, and B. argentea) are elongated in shape and are infaunal species. In comparison, $G$. subglobosa is more abundant in higher-oxygen environments and is a spherical, epifaunal species. This supports previous findings that infaunal vs. epifaunal habitat preference impacts the species distribution across the oxygenation gradient and that species in low-oxygen zones have lower volume-tosurface-area ratios relative to those in well-oxygenated areas (Kaiho, 1999; Keating-Bitonti and Payne, 2016, 2018; Venturelli et al., 2018). In general, infaunal species are more common within the OMZ, while epifaunal are more common in well-oxygenated areas (Kaiho, 1999).

Previous studies have categorized benthic foraminifera into categories of oxygenation based upon similar work combining in situ environmental conditions and assemblage data (Cannariato and Kennett, 1999; Douglas and Heitman, 1979; Kaiho, 1994; Moffitt et al., 2014). Our findings indicate that region (or environment) specific oxygen species associations may be necessary, as our findings do not align directly with previous categorization of species. Several species that were previously recognized as low-oxygen indicators $(B$. argentea, B. spissa, and U. peregrina) were found at all water depths in this study, but we find only very low abundances of two well-documented low-oxygen indicator species, Nonionella stella and Bolivina tumida (Bernhard et al., 1997; Bernhard and Gupta, 1999; Cannariato and Kennett, 1999; Moffitt et al., 2014). These taxa have documented adaptations to extreme environments; $B$. tumida is associated with methane seep environments (Hill et al., 2003), and N. stella is known to sequester symbionts or plastids in extreme conditions (Bernhard and Bowser, 1999) We hypothesize that the marginal environment studied here does not reach the extreme hypoxic to anoxic conditions that are suitable for $B$. tumida or N. stella. Several species of documented oxic indi- cators (Cibicidoides sp. and Quinqueloculina sp.) are found across all depths (300-1175 m) and oxygenation environments $\left(0.26-1.54 \mathrm{mLL}^{-1}\right)$ in the San Diego margin. Many past categorizations of these species were generated using species from very low oxygen basins (e.g., Santa Barbara Basin) where seasonal anoxia is present. The presence of oxic indicator species across all water depths on the San Diego margin may provide evidence for periodic flushing of high-oxygen water or a selection for species that can tolerate a range of environmental conditions rather than a specific threshold of oxygenation. Alternatively, these species may be able to tolerate lower dissolved oxygen than previously thought if other environmental conditions (including substrate) are favorable or they may be able to tolerate short periods of low-oxygen conditions (Burkett et al., 2016; KeatingBitonti and Payne, 2018; Venturelli et al., 2018) (Fig. 3). Further, habitat heterogeneity, including grain size (not measured here), may play a role in the determination of species assemblages at this site, particularly in low-oxygen areas in which the nature of the sediment matrix determines oxygenation of sediment porewater (Levin et al., 2010; Venturelli et al., 2018).

We document the presence of members of the Bolivina genera at all water depths, and in some intervals described here, bolivinids make up more than $50 \%$ of the total assemblage. Therefore, any changes in abundance of this genus alone can drive changes in the assemblages as a whole. Within-species variation of morphologic traits has been correlated with affinities for certain environmental conditions (Lutze, 1964), yet congeneric gradations such as those observed here in the bolivinid genera merit further investigation. While bolivinids are widely accepted as low-oxygen dwelling species, Bolivina argentea specifically has been utilized as a low-oxygen indicator taxon, and analysis of their abundance and distribution requires careful scrutiny (Cardich et al., 2015; Caulle et al., 2014; Mallon et al., 2012).

We identify an anomalous assemblage at $528 \mathrm{~m}$ water depth; this assemblage is the least diverse $(H=1.316$, in $>150 \mu \mathrm{m}$ size fraction). Importantly, the low diversity at this site is driven by the dominance of a single species, $B$. argentea. We observe the dominance of $B$. argentea at $528 \mathrm{~m}$ water depth, near the modern upper margin of the OMZ, and a lower relative abundance of this species at 700 and $800 \mathrm{~m}$ water depth, in the heart of the OMZ (Fig. 3). This pattern of $B$. argentea at high abundances near the upper margin of the OMZ has been previously observed (Douglas, 1981; Mullins et al., 1985), and these species are often used as indicators of dysoxic environments (Bernhard et al., 1997; Kaiho, 1999). We attribute some of the unexpected variability in benthic communities that does not correlate with bottom water oxygenation to edge effects of the OMZ. Specifically, there is more biologically available nitrate and nitrifying bacteria at the edges of the OMZ as compared to the center, and thus we expect greater nutrient concentrations and larger food availability in these zones (Mullins et al., 1985). Multiple species 
of benthic foraminifera respire nitrate in low-oxygen environments; in particular, $B$. argentea is particularly effective in utilizing nitrate as an alternative electron acceptor, and this may contribute to its dominance at the upper edge of the OMZ (Bernhard et al., 2012; Glock et al., 2019; Kuhnt et al., 2013). Additionally, seasonal or annual variability in oxygenation of the upper margin of the $\mathrm{OMZ}$ causing a variable oxygenation regime at $528 \mathrm{~m}$ may drive selection for species that can tolerate a range of environmental conditions rather than a specific threshold of oxygenation. Further, environmental and ecological factors may combine to drive assemblage diversity; the interactive effects of competition and environmental adaptation may promote habitat specialization at this water depth (Fine et al., 2004). While the sites measured here document changes in the upper margin of the OMZ (528 $\mathrm{m}$ site), they may exclude the lower margin of the OMZ due to sampling depths of coring sites.

\subsection{Temporal change in benthic foraminiferal assemblages records environmental change through time}

Following results of analysis across modern core tops, all down-core benthic foraminiferal assemblages were collected from the $>150 \mu \mathrm{m}$ size fraction. The combination of analyses from three distinct modern environments (upper margin of the OMZ, $528 \mathrm{~m}$; the center of the OMZ, $800 \mathrm{~m}$; and below the OMZ, $1175 \mathrm{~m}$ ) allows for reconstruction of oceanographic change through the water column. We acknowledge that the environment is more variable than we can describe given the record available. Oxygenation varies on seasonal, annual, and decadal timescales - yet each interval of sediment analyzed represents $>35$ years; thus we are capturing a time-averaged signal. Further, several factors complicate our ability to interpret benthic assemblage records: relative preservation of various shell types, postdepositional changes in sediment, dominant fauna within some assemblages that dominate responses, and high frequency variability not captured in the record. Yet, we are still able to analyze benthic foraminiferal assemblages to identify environmental changes through the time interval described here.

Integrating analysis of cores from multiple depths reveals decadal to centennial variability in oxygenation at the upper margin of the OMZ $(528 \mathrm{~m})$ during the last $1.5 \mathrm{kyr}$ but little to no change in the oxygenation at the center of the OMZ $(800 \mathrm{~m})$ or below the OMZ $(1175 \mathrm{~m})$ (Fig. 4). The change in assemblage at $528 \mathrm{~m}$ beginning at $400 \mathrm{BP}$ indicates a transition to the OMZ edge environment in which $B$. argentea and $U$. peregrina species dominate in the modern assemblage. The formation of an assemblage that is similar to the modern assemblage at $400 \mathrm{BP}$ implies the onset of modern conditions at this site which would include relatively low oxygen with variable oxygenation on seasonal to yearly timescales. We interpret the transition in assemblage as a decrease in oxygenation at this depth and a shoaling of the upper margin of the
OMZ beginning at $400 \mathrm{BP}$ and continuing to the present. The combined suite of foraminiferal assemblages reveals shoaling of the upper margin of the OMZ in the last 400 years, while the center of the OMZ and below the OMZ remained stable (Fig. 4). As such, we document an expansion of the upper margin of the OMZ beginning $\sim 1600 \mathrm{CE}$ and continuing to the present.

Our findings are consistent with observations from other regional records of oxygenation, including those from wellresolved records in nearby basins. The Santa Monica Basin (SMB) and Santa Barbara Basin (SBB) are silled basins that experience periodic flushing; changes in the strength or oxygen content of North Pacific Intermediate Water, stratification, or surface productivity can lead to changes in oxygenation within each basin (Balestra et al., 2018; Cannariato and Kennett, 1999; Schimmelmann et al., 2013). Marine sediment records from Santa Monica Basin show nonannual laminations (indicating a hypoxic to anoxic environment) beginning $400 \mathrm{BP}$ and document shoaling of the low-oxygen zone within the basin from $400 \mathrm{BP}$ to the present (Christensen et al., 1994). The Santa Barbara Basin has well-documented sediment laminations through most of the Holocene, indicating persistent low oxygen, but also shows gradual intensification of the OMZ within the SBB since 1850 CE (Wang et al., 2017).

The synchronous decrease in oxygenation in the Santa Monica Basin (Christensen et al., 1994) and San Diego margin (this study) from $400 \mathrm{BP}$ to the present indicates that this deoxygenation is not driven by basinal changes alone; rather it is likely driven by regional-scale phenomena. The decrease in oxygenation across the Southern California margin since $400 \mathrm{BP}$ could be attributed to (1) a change in oxygenation or strength of North Pacific Intermediate Water, (2) an increase in organic carbon flux from sea surface to depth driven by changes in surface productivity, or (3) a decrease in bottom water mixing or ventilation as a result of changes in surface water temperatures. We note that within the San Diego margin and Santa Monica Basin records, deoxygenation trends begin $\sim 400 \mathrm{BP}$ but continue or intensify in the last 200 years. In the last 150 years, deoxygenation is synchronous across the SBB, SMB and San Diego margin. In this interval, decreases in oxygenation may be due to an increase in organic carbon supply from terrestrial sources due to human land use change in the Southern California region, which has documented impacts on nearby benthic ecosystems (Tomasovych and Kidwell, 2017; Wang et al., 2017). Investigation of oxygenation change over time requires further research to identify forcing mechanisms for changes in the upper margin of the OMZ and to discern the relative impact of human and natural forcing in changing oxygenation across the last few centuries. 


\section{Conclusions}

This spatial and temporal analysis of benthic foraminifera assemblages across a modern oxygen gradient on the San Diego margin improves our understanding of the relationship between assemblages and their environment. Comparison of the relative abundance of benthic foraminifera in two size fractions $(63-150$ and $>150 \mu \mathrm{m})$ across the modern OMZ shows that trends are either similar in both size fractions or are more pronounced in the larger size fraction. As a result, we conclude that analysis of the $>150 \mu \mathrm{m}$ assemblage for this site provides the most useful record for interpreting benthic foraminifera as a proxy for past change. We identify two hypoxic-associated species (B. spissa, and U. peregrina), one oxic-associated species (G. subglobosa) and one OMZ edgeassociated species (B. argentea). Down-core analysis of indicator species reveals variability in the upper margin of the $\mathrm{OMZ}$ while the center of the OMZ remained stable in the last $1.5 \mathrm{kyr}$. At $528 \mathrm{~m}$, benthic foraminiferal assemblages indicate a decrease in oxygenation at this depth and a shoaling of the upper margin of the OMZ beginning at $400 \mathrm{BP}$ and continuing to the present. Expansion of the upper margin of OMZ beginning $400 \mathrm{BP}$ is synchronous with regional records of oxygenation.

Data availability. All data collected for this paper are electronically archived by the NOAA Paleoclimatology Database as "San Diego Margin Benthic Foraminiferal Assemblages from Late Holocene" at https://www.ncdc.noaa.gov/paleo-search/study/ 28290 (Palmer et al., 2019).

Supplement. The supplement related to this article is available online at: https://doi.org/10.5194/bg-17-2923-2020-supplement.

Author contributions. HMP, SEM, and TMH conceptualized and designed the project. HMP, SEM, JTD, and KRR completed data collection. HMP, TMH, and PDR completed data analysis. HMP wrote the manuscript. All authors contributed to editing of the manuscript.

Competing interests. The authors declare that they have no conflict of interest.

Special issue statement. This article is part of the special issue "Ocean deoxygenation: drivers and consequences - past, present and future (BG/CP/OS inter-journal SI)". It is not associated with a conference.

Acknowledgements. We would like to acknowledge the San Diego Coastal Expedition team for their work in collecting the oceano- graphic data and sediment cores used in this study, particularly PIs Christina Frieder and Benjamin Grupe. We thank Seth Finnegan and Sara Kahanamoku for their support in microscopy and imaging. We acknowledge two helpful reviewers that improved this paper.

Financial support. This research has been supported by the National Science Foundation, Division of Ocean Sciences (grant nos. 1444451 and 1832812); the Bilinski Foundation; the Geological Society of America; and the Cushman Foundation for Foraminiferal Research.

Review statement. This paper was edited by Tina Treude and reviewed by two anonymous referees.

\section{References}

Al-Sabouni, N., Fenton, I. S., Telford, R. J., and Kučera, M.: Reproducibility of species recognition in modern planktonic foraminifera and its implications for analyses of community structure, J. Micropalaeontol., 37, 519-534, https://doi.org/10.5194/jm-37-519-2018, 2018.

Bakun, A.: Climate change and ocean deoxygenation within intensified surface-driven upwelling circulations, Philos. T. R. Soc. A, 375, 20160327, https://doi.org/10.1098/rsta.2016.0327, 2017.

Balestra, B., Krupinski, N. B. Q., Erohina, T., Fessenden-Rahn, J., Rahn, T., and Paytan, A.: Bottom-water oxygenation and environmental change in Santa Monica Basin, Southern California during the last 23 kyr, Palaeogeogr. Palaeocl., 490, 17-37, 2018.

Balmaki, B., Wigand, P. E., Frontalini, F., Shaw, T. A., AvnaimKatav, S., and Rostami, M. A.: Late Holocene paleoenvironmental changes in the Seal Beach wetland (California, USA): A micropaleontological perspective, Quaternary Int., 530, 14-24, https://doi.org/10.1016/j.quaint.2019.10.012, 2019.

Bernhard, J. M. and Bowser, S. S.: Benthic foraminifera of dysoxic sediments: chloroplast sequestration and functional morphology, Earth-Sci. Rev., 46, 149-165, 1999.

Bernhard, J. M. and Gupta, B. K. S.: Foraminifera of oxygendepleted environments, in: Modern foraminifera, Springer, 201216, 1999.

Bernhard, J. M., Sen Gupta, B. K., and Borne, P. F.: Benthic foraminiferal proxy to estimate dysoxic bottom-water oxygen concentrations; Santa Barbara Basin, US Pacific continental margin, J. Foramin. Res., 27, 301-310, 1997.

Bernhard, J. M., Casciotti, K. L., McIlvin, M. R., Beaudoin, D. J., Visscher, P. T., and Edgcomb, V. P.: Potential importance of physiologically diverse benthic foraminifera in sedimentary nitrate storage and respiration, J. Geophys. Res.-Biogeo., 117, G03002, https://doi.org/10.1029/2012JG001949, 2012.

Bograd, S. J., Castro, C. G., Di Lorenzo, E., Palacios, D. M., Bailey, H., Gilly, W., and Chavez, F. P.: Oxygen declines and the shoaling of the hypoxic boundary in the California Current, Geophys. Res. Lett., 35, L12607, https://doi.org/10.1029/2008g1034185, 2008.

Breitburg, D., Levin, L. A., Oschlies, A., Gregoire, M., Chavez, F. P., Conley, D. J., Garcon, V., Gilbert, D., Gutierrez, D., Isensee, K., Jacinto, G. S., Limburg, K. E., Montes, I., Naqvi, S. W. A., Pitcher, G. C., Rabalais, N. N., Roman, M. R., Rose, K. A., 
Seibel, B. A., Telszewski, M., Yasuhara, M., and Zhang, J.: Declining oxygen in the global ocean and coastal waters, Science, 359, 1-32, https://doi.org/10.1126/science.aam7240, 2018.

Burkett, A. M., Rathburn, A. E., Elena Pérez, M., Levin, L. A., and Martin, J. B.: Colonization of over a thousand Cibicidoides wuellerstorfi (foraminifera: Schwager, 1866) on artificial substrates in seep and adjacent off-seep locations in dysoxic, deep-sea environments, Deep-Sea Res. Pt. I, 117, 3950, https://doi.org/10.1016/j.dsr.2016.08.011, 2016.

Cannariato, K. G. and Kennett, J. P.: Climatically related millennial-scale fluctuations in strength of California margin oxygen-minimum zone during the past $60 \mathrm{ky}$, Geology, 27, 975-978, https://doi.org/10.1130/00917613(1999)027<0975:Crmsfi>2.3.Co;2, 1999.

Cardich, J., Gutiérrez, D., Romero, D., Pérez, A., Quipúzcoa, L., Marquina, R., Yupanqui, W., Solís, J., Carhuapoma, W., Sifeddine, A., and Rathburn, A.: Calcareous benthic foraminifera from the upper central Peruvian margin: control of the assemblage by pore water redox and sedimentary organic matter, Mar. Ecol. Prog. Ser., 535, 63-87, https://doi.org/10.3354/meps11409, 2015.

Cardich, J., Sifeddine, A., Salvatteci, R., Romero, D., BriceñoZuluaga, F., Graco, M., Anculle, T., Almeida, C., and Gutiérrez, D.: Multidecadal Changes in Marine Subsurface Oxygenation Off Central Peru During the Last ca. 170 Years, Front. Mar. Sci., 6, 270 pp., https://doi.org/10.3389/fmars.2019.00270, 2019.

Caulle, C., Koho, K. A., Mojtahid, M., Reichart, G. J., and Jorissen, F. J.: Live (Rose Bengal stained) foraminiferal faunas from the northern Arabian Sea: faunal succession within and below the OMZ, Biogeosciences, 11, 1155-1175, https://doi.org/10.5194/bg-11-1155-2014, 2014.

Checkley, D. M. and Barth, J. A.: Patterns and processes in the California Current System, Prog. Oceanogr., 83, 49-64, https://doi.org/10.1016/j.pocean.2009.07.028, 2009.

Christensen, C. J., Gorsline, D. S., Hammond, D. E., and Lund, S. P.: Non-annual laminations and expansion of anoxic basin-floor conditions in Santa Monica Basin, California Borderland, over the past four centuries, Mar. Geol., 116, 399-418, 1994.

De Villiers, S.: Optimum growth conditions as opposed to calcite saturation as a control on the calcification rate and shell-weight of marine foraminifera, Mar. Biol., 144, 45-49, 2004.

Douglas, R.: Paleoecology of Continental Margin Basins: A modern case history from the borderland of Southern California, Depositional System of Active Continental Margin Basins-Short Course Notes, 121-156, 1981.

Douglas, R. G. and Heitman, H. L.: Slope and basin benthic foraminifera of the California borderland, Society of Economic Paleontologists and Mineralogists Special Publication, 27, 231246, 1979.

Emmer, E. and Thunell, R. C.: Nitrogen isotope variations in Santa Barbara Basin sediments: Implications for denitrification in the eastern tropical North Pacific during the last 50,000 years, Paleoceanography, 15, 377-387, https://doi.org/10.1029/1999pa000417, 2000.

Erdem, Z. and Schönfeld, J.: Pleistocene to Holocene benthic foraminiferal assemblages from the Peruvian continental margin, Palaeontol. Electron., 1-32, https://doi.org/10.26879/764, 2017.

Erdem, Z., Schönfeld, J., Rathburn, A. E., Pérez, M.-E., Cardich, J., and Glock, N.: Bottom-water deoxygena- tion at the Peruvian Margin during the last deglaciation recorded by benthic foraminifera, Biogeosciences Discuss., https://doi.org/10.5194/bg-2019-112, in review, 2019.

Fine, P. V. A., Mesones, I., and Coley, P. D.: Herbivores promote habitat specialization by trees in amazonian forests, Science, 305, 663-665, https://doi.org/10.1126/science.1098982, 2004.

Fisler, J. and Hendy, I. L.: California Current System response to late Holocene climate cooling in southern California, Geophys. Res. Lett., 35, L09702, https://doi.org/10.1029/2008g1033902, 2008.

Fox, L., Liebrand, D., Giles Miller, C., Roseby, Z. A., Stukins, S., Taylor, B., Pearson, P. N., Wade, B. S., and Purvis, A.: Factors affecting consistency and accuracy in identifying modern macroperforate planktonic foraminifera, J. Micropalaeontol., 37, 431443, 2018.

Friddell, J. E., Thunell, R. C., Guilderson, T. P., and Kashgarian, M.: Increased northeast Pacific climatic variability during the warm middle Holocene, Geophys. Res. Lett., 30, 1560, doi:10.1029/2002GL016834, 2003.

Gilly, W. F., Beman, J. M., Litvin, S. Y., and Robison, B. H.: Oceanographic and Biological Effects of Shoaling of the Oxygen Minimum Zone, Annu. Rev. Mar. Sci., 5, 393-420, https://doi.org/10.1146/annurev-marine-120710-100849, 2013.

Glock, N., Roy, A.-S., Romero, D., Wein, T., Weissenbach, J., Revsbech, N. P., Høgslund, S., Clemens, D., Sommer, S., and Dagan, T.: Metabolic preference of nitrate over oxygen as an electron acceptor in foraminifera from the Peruvian oxygen minimum zone, P. Natl. Acad. Sci. USA, 116, 2860-2865, https://doi.org/10.1073/pnas.1813887116, 2019.

Gooday, A. J.: Benthic foraminifera (Protista) as tools in deep-water palaeoceanography: environmental influences on faunal characteristics, Adv. Mar. Bio., 46, 1-90, 2003.

Gooday, A. J., Bernhard, J. M., Levin, L. A., and Suhr, S. B.: Foraminifera in the Arabian Sea oxygen minimum zone and other oxygen-deficient settings: taxonomic composition, diversity, and relation to metazoan faunas, Deep-Sea Res. Pt. II, 47, 25-54, 2000.

Grupe, B. M., Krach, M. L., Pasulka, A. L., Maloney, J. M., Levin, L. A., and Frieder, C. A.: Methane seep ecosystem functions and services from a recently discovered southern California seep, Mar. Ecol.-Evol. Persp., 36, 91-108, https://doi.org/10.1111/maec.12243, 2015.

Helly, J. J. and Levin, L. A.: Global distribution of naturally occurring marine hypoxia on continental margins, Deep-Sea Res. Pt. I, 51, 1159-1168, https://doi.org/10.1016/j.dsr.2004.03.009, 2004.

Hendy, I. L.: The paleoclimatic response of the Southern Californian Margin to the rapid climate change of the last $60 \mathrm{ka}$ : A regional overview, Quaternary Int., 215, 62-73, 2010.

Hendy, I. L. and Kennett, J. P.: Dansgaard-Oeschger cycles and the California Current System: Planktonic foraminiferal response to rapid climate change in Santa Barbara Basin, Ocean Drilling Program hole 893A, Paleoceanography, 15, 30-42, https://doi.org/10.1029/1999pa000413, 2000.

Hill, T. M., Kennett, J. P., and Spero, H. J.: Foraminifera as indicators of methane-rich environments: a study of modern methane seeps in Santa Barbara Channel, California, Mar. Micropaleontol., 49, 123-138, 2003.

Hsiang, A. Y., Brombacher, A., Rillo, M. C., Mleneck-Vautravers, M. J., Conn, S., Lordsmith, S., Jentzen, A., Henehan, M. J., Met- 
calfe, B., Fenton, I. S., Wade, B. S., Fox, L., Meilland, J., Davis, C. V., Baranowski, U., Groeneveld, J., Edgar, K. M., Movellan, A., Aze, T., Dowsett, H. J., Miller, C. G., Rios, N., and Hull, P. M.: Endless Forams: $>34,000$ Modern Planktonic Foraminiferal Images for Taxonomic Training and Automated Species Recognition Using Convolutional Neural Networks, Paleoceanogr. Paleocl., 34, 1157-1177, https://doi.org/10.1029/2019PA003612, 2019.

Ingram, B. L. and Southon, J. R.: Reservoir ages in eastern Pacific coastal and estuarine waters, Radiocarbon, 38, 573-582, 1996.

Jaccard, S. L., Galbraith, E. D., Frolicher, T. L., and Gruber, N.: Ocean (De)Oxygenation across the Last Deglaciation Insights for the Future, Oceanography, 27, 26-35, 2014.

Jorissen, F. J., de Stigter, H. C., and Widmark, J. G. V.: A conceptual model explaining benthic foraminiferal microhabitats, Mar. Micropaleontol., 26, 3-15, https://doi.org/10.1016/03778398(95)00047-X, 1995.

Jorissen, F. J., Fontanier, C., and Thomas, E.: Chapter Seven Paleoceanographical Proxies Based on Deep-Sea Benthic Foraminiferal Assemblage Characteristics, in: Developments in Marine Geology, Vol. 1, Elsevier, 263-325, 2007.

Kaiho, K.: Benthic Foraminiferal Dissolved-Oxygen Index and Dissolved-Oxygen Levels in the Modern Ocean, Geology, 22, 719-722, https://doi.org/10.1130/00917613(1994)022<0719:Bfdoia>2.3.Co;2, 1994.

Kaiho, K.: Effect of organic carbon flux and dissolved oxygen on the benthic foraminiferal oxygen index (BFOI), Mar. Micropaleontol., 37, 67-76, https://doi.org/10.1016/S03778398(99)00008-0, 1999.

Keating-Bitonti, C. R. and Payne, J. L.: Physicochemical controls on biogeographic variation of benthic foraminiferal test size and shape, Paleobiology, 42, 595-611, 2016.

Keating-Bitonti, C. R. and Payne, J. L.: Ecophenotypic responses of benthic foraminifera to oxygen availability along an oxygen gradient in the California Borderland, Mar. Ecol., 38, e12430, 2017.

Keating-Bitonti, C. R. and Payne, J. L.: Environmental influence on growth history in marine benthic foraminifera, Paleobiology, 44, 736-757, https://doi.org/10.1017/pab.2018.19, 2018.

Kuhnt, T., Friedrich, O., Schmiedl, G., Milker, Y., Mackensen, A., and Lückge, A.: Relationship between pore density in benthic foraminifera and bottom-water oxygen content, Deep-Sea Res. Pt. I, 76, 85-95, https://doi.org/10.1016/j.dsr.2012.11.013, 2013.

Levin, L. A.: Oxygen minimum zone benthos: Adaptation and community response to hypoxia, Oceanogr. Mar. Biol., 41, 1-45, 2003.

Levin, L. A. and Dayton, P. K.: Ecological theory and continental margins: where shallow meets deep, Trends Ecol. Evol., 24, 606617, https://doi.org/10.1016/j.tree.2009.04.012, 2009.

Levin, L. A., Ekau, W., Gooday, A. J., Jorissen, F., Middelburg, J. J., Naqvi, S. W. A., Neira, C., Rabalais, N. N., and Zhang, J.: Effects of natural and human-induced hypoxia on coastal benthos, Biogeosciences, 6, 2063-2098, https://doi.org/10.5194/bg6-2063-2009, 2009.

Levin, L. A., Sibuet, M., Gooday, A. J., Smith, C. R., and Vanreusel, A.: The roles of habitat heterogeneity in generating and maintaining biodiversity on continental margins: an introduction, Mar. Ecol.-Evol. Persp., 31, 1-5, https://doi.org/10.1111/j.14390485.2009.00358.x, 2010.
Lutze, G. F.: Statistical Investigations of the variability of Bolivina argentea Cushman, Contributions from te Cushman Foundation for Foraminiferal Research, XV, 15, 105-116, 1964.

Mallon, J., Glock, N., and Schönfeld, J.: The Response of Benthic Foraminifera to Low-Oxygen Conditions of the Peruvian Oxygen Minimum Zone, in: Anoxia: Evidence for Eukaryote Survival and Paleontological Strategies, edited by: Altenbach, A. V., Bernhard, J. M., and Seckbach, J., Springer Netherlands, Dordrecht, 305-321, 2012.

Mazumder, A. and Nigam, R.: Bathymetric preference of four major genera of rectilinear benthic foraminifera within oxygen minimum zone in Arabian Sea off central west coast of India, J. Earth Syst. Sci., 123, 633-639, https://doi.org/10.1007/s12040014-0419-y, 2014.

McGann, M.: Historical and modern distributions of benthic foraminifers on the continental shelf of Monterey Bay, California, Mar. Geol., 181, 115-156, https://doi.org/10.1016/S00253227(01)00264-X, 2002.

Moffitt, S. E., Hill, T. M., Ohkushi, K., Kennett, J. P., and Behl, R. J.: Vertical oxygen minimum zone oscillations since $20 \mathrm{ka}$ in Santa Barbara Basin: A benthic foraminiferal community perspective, Paleoceanography, 29, 44-57, https://doi.org/10.1002/2013pa002483, 2014.

Moffitt, S. E., Moffitt, R. A., Sauthoff, W., Davis, C. V., Hewett, K., and Hill, T. M.: Paleoceanographic insights on recent oxygen minimum zone expansion: lessons for modern oceanography, PLoS One, 10, e0115246, https://doi.org/10.1371/journal.pone.0115246, 2015a.

Moffitt, S. E., Hill, T. M., Roopnarine, P. D., and Kennett, J. P.: Response of seafloor ecosystems to abrupt global climate change, P. Natl. Acad. Sci. USA, 112, 4684-4689, https://doi.org/10.1073/pnas.1417130112, 2015b.

Mullins, H. T., Thompson, J. B., Mcdougall, K., and Vercoutere, T. L.: Oxygen-Minimum Zone Edge Effects Evidence from the Central California Coastal Upwelling System, Geology, 13, 491-494, https://doi.org/10.1130/00917613(1985)13<491:Ozeeef>2.0.Co;2, 1985.

Myhre, S. E., Kroeker, K. J., Hill, T. M., Roopnarine, P., and Kennett, J. P.: Community benthic paleoecology from high-resolution climate records: Mollusca and foraminifera in post-glacial environments of the California margin, Quaternary Sci. Rev., 155, 179-197, https://doi.org/10.1016/j.quascirev.2016.11.009, 2017.

Nam, S., Takeshita, Y., Frieder, C. A., Martz, T., and Ballard, J.: Seasonal advection of Pacific Equatorial Water alters oxygen and $\mathrm{pH}$ in the Southern California Bight, J. Geophys. Res.-Ocean., 120, 5387-5399, https://doi.org/10.1002/2015jc010859, 2015.

Ohkushi, K., Kennett, J. P., Zeleski, C. M., Moffitt, S. E., Hill, T. M., Robert, C., Beaufort, L., and Behl, R. J.: Quantified intermediate water oxygenation history of the NE Pacific: A new benthic foraminiferal record from Santa Barbara basin, Paleoceanography, 28, 453-467, https://doi.org/10.1002/palo.20043, 2013.

Oksanen, J., Blanchet, F. G., Kindt, R., Legendre, P., Minchin, P. R., O’hara, R. B., Simpson, G. L., Solymos, P., Stevens, M. H. H., and Wagner, H.: Package "vegan", Community ecology package, version 2, 5 pp., 2013.

Palmer, H. M., Hill, T. M., Myhre, S. E., Roopnarine, P. R., Reyes, K. R., and Donnenfield, J. T.: San Diego Margin Benthic Foraminiferal Assemblages from Late Holocene, NOAA 
Paleoclimate Database, available at: https://www.ncdc.noaa.gov/ paleo-search/study/28290 (last access: 20 April 2020), 2019.

Peet, R. K.: The measurement of species diversity, Annu. Rev. Ecol. Syst., 5, 285-307, 1974.

Rathburn, A. E., Willingham, J., Ziebis, W., Burkett, A. M., and Corliss, B. H.: A New biological proxy for deep-sea paleooxygen: Pores of epifaunal benthic foraminifera, Sci. Rep., 8, 9456, https://doi.org/10.1038/s41598-018-27793-4, 2018.

Roark, E. B., Ingram, B. L., Southon, J., and Kennett, J. P.: Holocene foraminiferal radiocarbon record of paleocirculation in the Santa Barbara Basin, Geology, 31, 379-382, https://doi.org/10.1130/00917613(2003)031<0379:Hfrrop>2.0.Co;2, 2003.

Schimmelmann, A., Hendy, I. L., Dunn, L., Pak, D. K., and Lange, C. B.: Revised similar to 2000-year chronostratigraphy of partially varved marine sediment in Santa Barbara Basin, California, Gff, 135, 258-264, https://doi.org/10.1080/11035897.2013.773066, 2013.

Schmidtko, S., Stramma, L., and Visbeck, M.: Decline in global oceanic oxygen content during the past five decades, Nature, 542, 335-339, https://doi.org/10.1038/nature21399, 2017.

Setoyama, E. and Kaminski, M.: Neogene Benthic Foraminifera from the southern Bering Sea (IODP Expedition 323), Palaeontol. Electron., 1-30, https://doi.org/10.26879/462, 2015.

Shibahara, A., Ohkushi, K., Kennett, J. P., and Ikehara, K.: Late Quaternary changes in intermediate water oxygenation and oxygen minimum zone, northern Japan: A benthic foraminiferal perspective, Paleoceanography, 22, Pa3213, https://doi.org/10.1029/2005pa001234, 2007.

Stott, L. D., Neumann, M., and Hammond, D.: Intermediate water ventilation on the northeastern Pacific margin during the late Pleistocene inferred from benthic foraminiferal delta C-13, Paleoceanography, 15, 161-169, https://doi.org/10.1029/1999pa000375, 2000.
Stramma, L., Johnson, G. C., Firing, E., and Schmidtko, S.: Eastern Pacific oxygen minimum zones: Supply paths and multidecadal changes, J. Geophys. Res.-Ocean., 115, C09011, 2010.

Stuiver, M. and Polach, H. A.: Discussion reporting of ${ }^{14} \mathrm{C}$ data, Radiocarbon, 19, 355-363, 1977.

Takeshita, Y., Frieder, C. A., Martz, T. R., Ballard, J. R., Feely, R. A., Kram, S., Nam, S., Navarro, M. O., Price, N. N., and Smith, J. E.: Including high-frequency variability in coastal ocean acidification projections, Biogeosciences, 12, 5853-5870, https://doi.org/10.5194/bg-12-5853-2015, 2015.

Taylor, M. A., Hendy, I. L., and Pak, D. K.: The California Current System as a transmitter of millennial scale climate change on the northeastern Pacific margin from 10 to $50 \mathrm{ka}$, Paleoceanography, 30, 1168-1182, https://doi.org/10.1002/2014pa002738, 2015.

Tetard, M., Licari, L., and Beaufort, L.: Oxygen history off Baja California over the last $80 \mathrm{kyr}$ : A new foraminiferal-based record, Paleoceanography, 32, 246-264, https://doi.org/10.1002/2016PA003034, 2017.

Tomasovych, A. and Kidwell, S. M.: Nineteenth-century collapse of a benthic marine ecosystem on the open continental shelf, P. Roy. Soc. B, 284, 20170328, https://doi.org/10.1098/rspb.2017.0328, 2017.

Venturelli, R. A., Rathburn, A., Burkett, A., and Ziebis, W.: Epifaunal Foraminifera in an Infaunal World: Insights Into the Influence of Heterogeneity on the Benthic Ecology of Oxygen-Poor, DeepSea Habitats, Front. Mar. Sci., 5, 344 pp., 2018.

Wang, Y., Hendy, I., and Napier, T. J.: Climate and Anthropogenic Controls of Coastal Deoxygenation on Interannual to Centennial Timescales, Geophys. Res. Lett., 11528-11536, 2017. 